D) Check for updates

Cite this as: $B M J 2021 ; 372: m 4946$ http://dx.doi.org/10.1136/bmj.m4946 Published: 18 January 2021

\section{Acute management of myocardial infarction with ST-segment elevation: summary of NICE guidance}

Clarification-This NICE guideline summary (BMJ 2013;347:f4006, doi:10.1136/bmj.f4006) has now been superseded by a summary of updated guidance at www.bmj.com/content/371/bmj.m476o. 